\title{
Development of a digital model for public administration quality of real estate in the Russian Federation based on international experience
}

\author{
Olga Gvozdeva ${ }^{1 *}$, ElenaKolbneva ${ }^{2}$, Yulia Sinitsa $^{1}$, Marina Smirnova ${ }^{1}$, Ilya $_{\text {Chuksin }}{ }^{1}$ \\ ${ }^{1}$ State University of Land Use Planning, 15, Kazakova St., Moscow 105064, Russia \\ ${ }^{2}$ Voronezh State Agrarian University named after Emperor Peter the Great, 1, Michurina St., Voronezh 394087, Russia
}

\begin{abstract}
The authors studied the issues of recent changes in the system of state management of real estate.According to the authors it is necessary to use digital technologies of big data, neurotechnologies, artificial intelligence, new production technologies, and distributed registry systems for the formation of a digital economy.This will allow defining digitalization as the main source of long-term economic growth. The authors analyzed scientific research on the competition for global digitalization trends and determined the following: mobile Internet, e-commerce, artificial intelligence, however Blockchain technologies and visual identity are considered to be more promising and breakthrough trends. In order to assess the growth rate of the digital economy in the Russian Federation, the authors conduct the analysis in the studied area on the basis of quantitative and qualitative indicators of foreign leading countries. The authors come to the conclusion that the main result of digitalization is the increase in revenue, the increase in the speed of provision of services and their quality and the decrease in resource intensity.
\end{abstract}

\section{Introduction}

In the course of recent changes, the system of public administration of real estate is considered as the main factor indicator of development in digital economy taking into account its digitalization.The process of digitalization of the economic sectors of the Russian Federation is aimed at to achieve economic, social and technological effects that allow the country to provide a decent level of development and a stable competitive environment in the global market. During the formation of digital economy, the process of changing the traditional forms of established economic relations into digital form starts to prevail, which creates the undoubted potential of digital economy to increase the viability and security of the country.

It is necessary to take into account the quantitative and qualitative indicators of foreign countries in the studied industry and assess the state of the country in the international arena for an independent assessment of the growth rate of digital economy in the Russian Federation.For example, in the United States, the volume of digital economy is quite high, significant gross domestic product (GDP) is explained by intensive investment in digitalization, including attracting funds from the state and consolidated budget.Today, according to statistics from the relevant services, the share of digital economy in the United States is $10.9 \%$, in China $10 \%$, in the EU $-8.3 \%$.

The high specific indicator of the United States is explained by the introduction of large-scale information and digital solutions in digitalization system, as well as the development of its own projects "Alibaba" and "Huawei" [1].

The opinions of Russian experts in the field of the growth rate of digital economy in the Russian Federation agree that the country is lagging behind the leading countries in integrated development. In particular, according to the Digital McKinsey expert group, digitalization is a source of long-term economic growth, driven by the tools presented in Figure 1:

optimization of operations in production and logistics

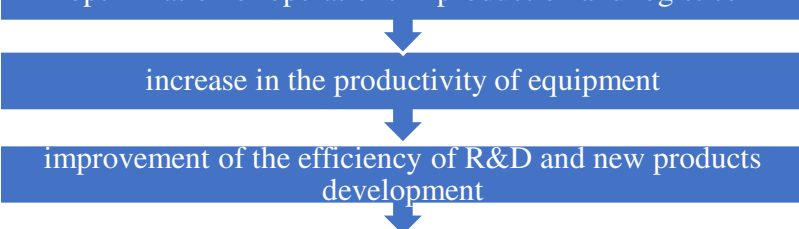

reduction of resource consumption and production losses

labor market improvement

Figure 1. Activities aimed at to achieve long-term economic growth in the context of the digitalization of economy

For the formation of digital economy, it is planned to use digital technologies of big data, neurotechnologies, 
artificial intelligence, new production technologies and blockchain systems [2].

On the basis of Rostelecom Company, scientific research was carried out to find global trends in digitalization. The trends were the following: mobile Internet, e-commerce, artificial intelligence, while more promising and breakthrough trends were Blockchain technologies and visual identification of a person, capable to identify and to establish the identity of a consumer of a service. In the global ranking of the development of digitalization trends, the Russian Federation ranks the $11^{\text {th }}$ place [3].

In the studies [3], the main problems of the introduction of digitalization are presented, including (Figure 2):

incorrectly set goals and objectives of the project of digitalization
$\begin{aligned} & \text { incorrect initial information about the object of implementation of } \\ & \text { digital solutions }\end{aligned}$
errors in planning the types and sequence of works
technological incompetence of users
economic uncertainty in the country
digital inequality of regions
lack of special measures of state support for the use of digital
technologies by companies

Figure 2. Main problems of introducing digitalization

The purpose of digitalization for the next 15-20 years is to take a leading position in the global economy through digital industry transformation and a competitive national digital industry.

\section{Materials and methods}

The importance of the study of the category of quality of public administration, both in general and in particular is explained in many scientific works that define quality as a basic key characteristic of public administration that has an impact on the development of the state.

In 2008, under the direction of V.V. Markin and A.V. Ostashkov, the studies on the the toolkit of the quality strategy of public and municipal administration within the framework of the modern concept of public administration were described in one of the first domestic publications on the identification of the concept of public administration quality.In this paper, the quality of public administration is understood as a different range of characteristics of the state and its departmental institutions, based on the unity of the three branches of government - legislative, executive, judicial, and transparency and observance of the rule of law.Ultimately, the quality of public administration is manifested in its direct impact on the socio-economic development of Russia and its regions.

A narrow understanding of public administration is determined in terms of the effectiveness of administration, the effectiveness of its organization and the rationality of institutions and functions of the executive branch.

E.V. Talapina, points out [4] that the quality of public administration can not be objectively assessed within the state apparatus itself. It is necessary to develop a quality assessment system that takes into account the satisfaction of participants in public administration - citizens, civil society institutions and business structures. The category of public administration quality can include three approaches (Figure 3):

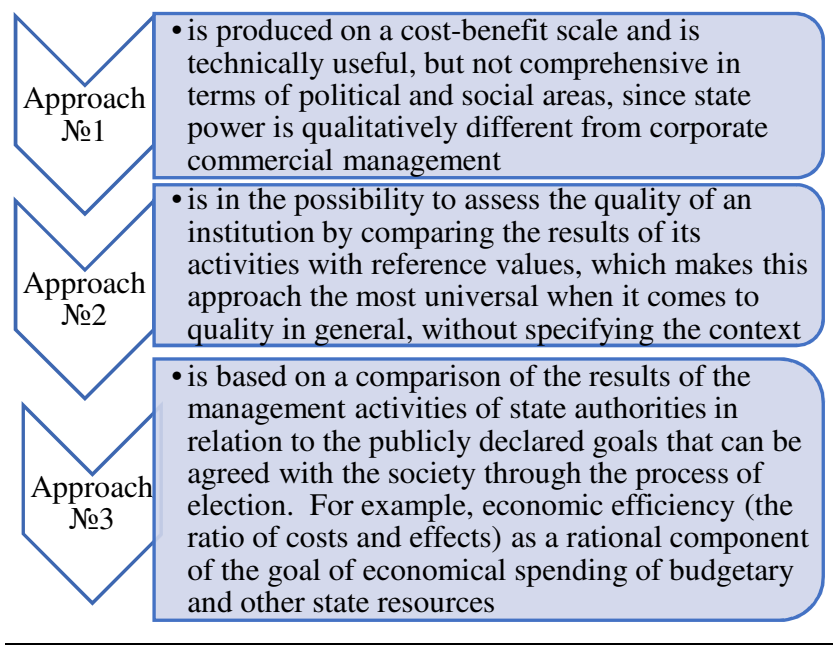

Figure 3. Approaches to the category of quality of public administration

In the world scientific literature, the concept of public administration quality is closely related to two prevailing concepts of public administration over the past decades: New Public Management and Good Governance.

The main goal of the New Public Management model is to increase the efficiency and effectiveness of the public administration system.

World Bank experts N. Manning and N. Parison [5] determined several goals of transformation, common for all states, related to (Figure 4):

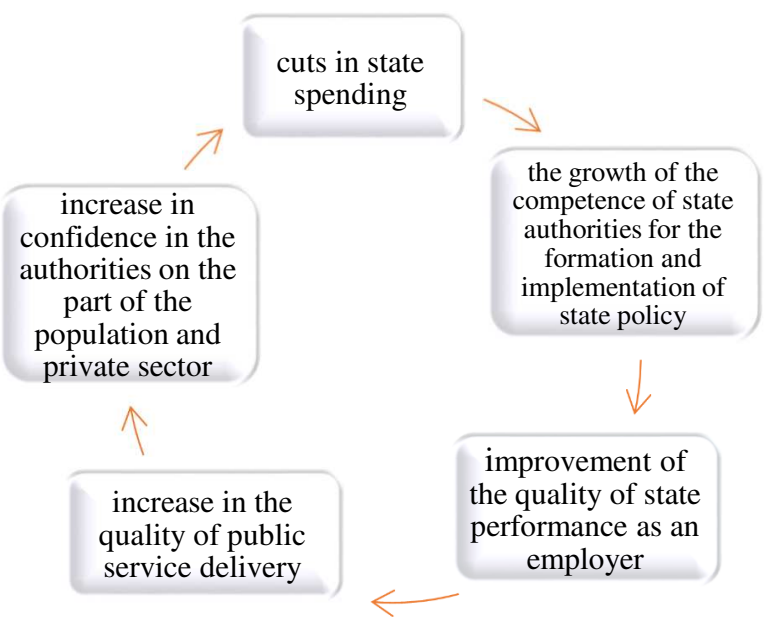

Figure 4. Ways to the goals of state transformation based on developing sectors of digital economy 
New Public Management and managerial principles of state governance are not general due to the fact that they move into the background "social mission" of the state, as a result of which, citizens are considered not as a source of political power, but as consumers of state and municipal services.

According to D.G. Krasilnikov [6] the concept of Governance, which is an independent management model, is defined as the content of administrative reforms that began in Western countries and spread to the rest of the world. Itcontains the parameters of the ideal management model, which can be used in the analysis to determine the degree of deviation from the sample, i.e. in terms of management quality.

The most common international assessment of the quality of national governance is the Governance Research Indicator Country Snapshot (GRICS), calculated every two years since 1996 for almost 200 countries. The indicator is developed on the basis of more than several hundred variables, indices and research results that serve as indicators of good governance of government bodies and include:

1) the mechanisms for the selection and management of government activities;

2) the ability of the state to clearly and concretely formulate and define the policy of the state;

3) respectful attitude of citizens and the state to the institutions that manage social and economic interactions in society.

Six GRICS indexes include (Figure 5):

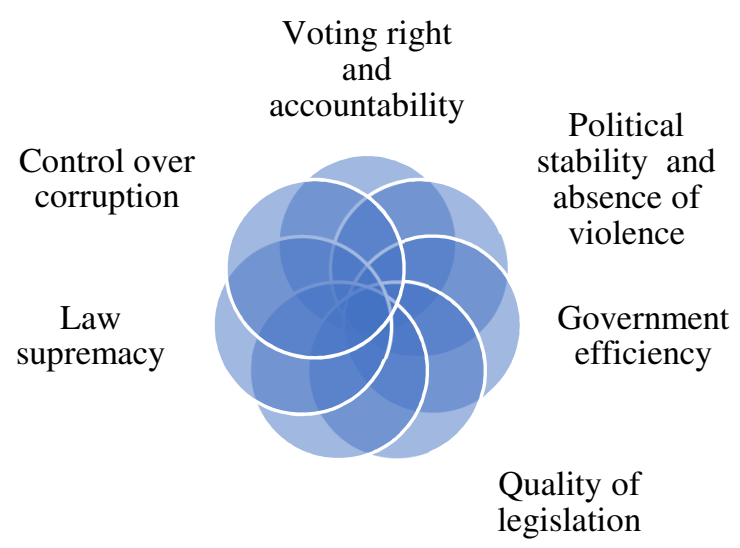

Figure 5. GRICS indicators
Among other indicators of the quality of public administration, the majority of indicators are based on a methodology to assess it with a narrower approach. For example such indices are presented in Figure 6:

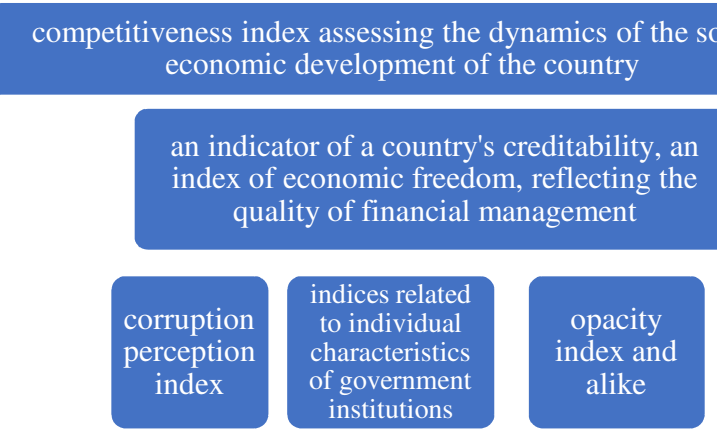

Figure 6. Indicators of the quality of public administration

The Growth Competitiveness Index (GCI), which is supported by the World Economic Forum and includes the assessment of the quality of public institutions, is quite popular.The index includes nine components, among which the state of public institutions stands apart, expertly assessed by such parameters as the provision of property rights, the state of ethics and the level of corruption, undue influence (favoritism, etc.) and government efficiency. All these parameters relate to the basic conditions for the provision of economic growth.

The Corruption Perception Index (CPI) is a composite index developed by the international nongovernmental organization Transparency International, which has been calculating CPI annually since 1995 using a methodology based on the results of its surveys. The main purpose of this index is to present the current state of the level of corruption in the country. The Corruption Perception Index is based on data from 17 different surveys and studies conducted by 13 independent institutions among entrepreneurs and local analysts, including surveys of the population (both its citizens and foreigners).

At the same time, Russian researchers [7] note that in Russia international methodsto assess the effectiveness of public administration are not used fully and systematically during the determination of the quality of public administration.

The dynamics of GRICS can be demonstrated according to the data of the World Bank [8] and in Figure 7. 


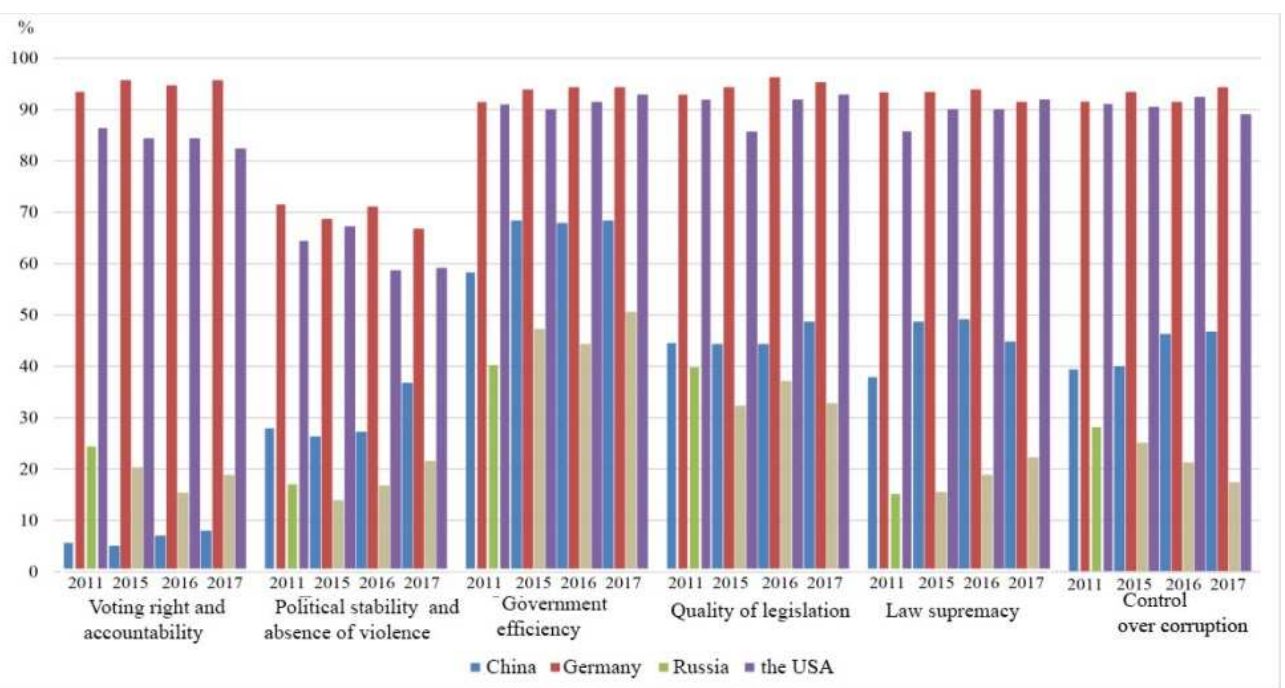

Figure 7.World Bank Percentile Ranking of Governance Indicators for the period 2011 - 2017 [8]

After the analysis of the ranking of leaders in terms of indicators, we can conclude that Germany has the highest quantitative values by all indicators. The indicators of the Russian Federation are significantly lower in comparison with other countries throughout the period.For example, in 2017, Germany exceeded Russia by 5.1 times in terms of voting rights and tax reporting and 2.9 times in terms of quality of government regulation.

Thus, we can say that in Russia there are serious problems in the formation of public administration in all the studied indicators.

The indicators of the quality of public real estate management were classified into 2 groups and 11 subgroups (Figure 8):

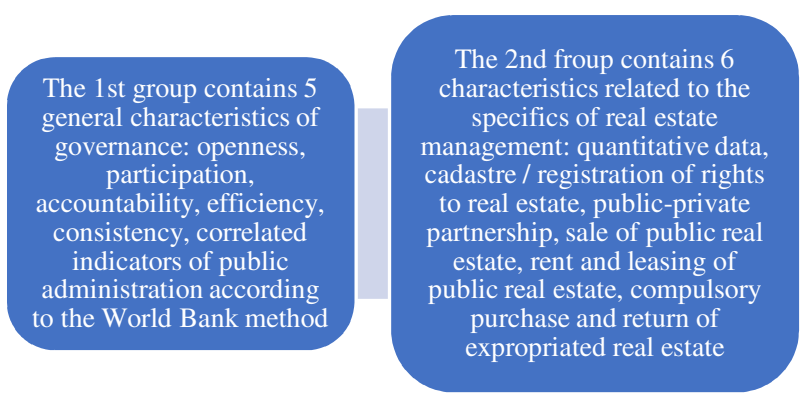

Figure 8. World Bank Percentile Ranking of Governance Indicators for the period $2011-2017$ [8]

The figures 9 and 10 show the assessments of the presented characteristics of the quality of state property management in the context of indicators of subgroups. They show that in Russia there was a rather low level of quality of state property management.

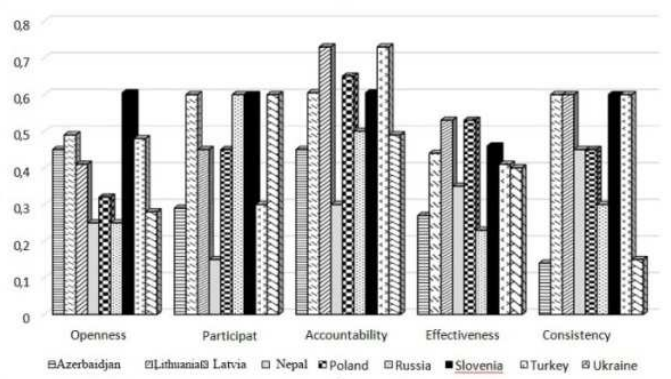

Figure 9.Assessment of the characteristics of the 1st group of quality management of public real estate [9]

According to the studies of indicators of the quality of public administration in the field of real estate (Figures 9-10), the definition of such indicators has significant drawbacks associated with the lack of quality information and methodological flaws that relate to the overall suitability of real estate.

The problems of the quality of public administration in general in the Russian Federation have a large number of issues and are not properly studied, namely, the key categories and theoretical provisions of public administration of real estate are not fully revealed.

Nowadays in accordance with the list of state programs of the Russian Federation, approved by the order of the Government of November 11, 2010 No. 1950-r, 44 state programs are provided. These state programs are represented by five program blocks. At the same time, the effectiveness of the implementation of government programs is $78-95 \%$ [9]. The main goals of the program are in the context of the increase in the efficiency and quality of public administration in terms of federal property and material reserves [9]. 


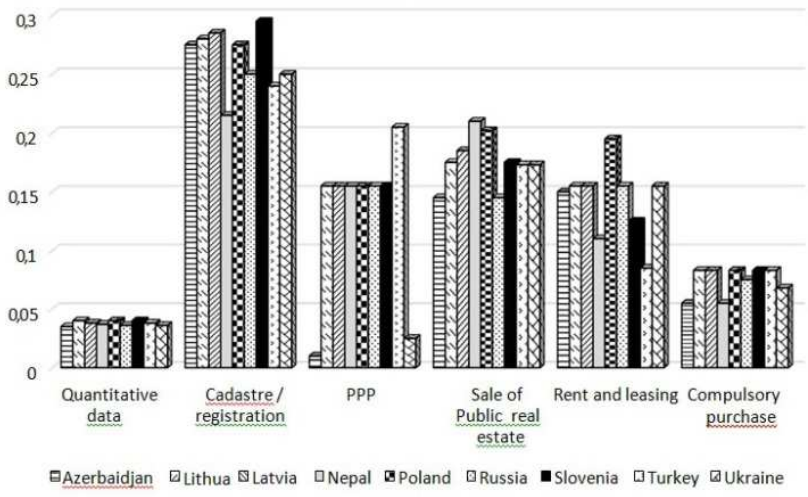

Figure 10. Assessment of the characteristics of the $2^{\text {nd }}$ group of quality management of public real estate [9]

In the Russian scientific literature, the developments on qualimetric and vector analysis of quality are also actively carried out, including in the field of real estate management, which often requires expert methods and multicriteria analysis [9].

\section{Results and Discussion}

According to the research results of the Boston Consulting Group, the expected digitalization results of public administration are presented in Table 1 [9].

Table 1 - Forecasts of the results of digitalization in public administration [9]

\begin{tabular}{|c|c|c|c|}
\hline $\begin{array}{c}\text { Indicators and types of } \\
\text { services }\end{array}$ & 2018 & 2019 & 2020 \\
\hline $\begin{array}{l}\text { Number of government } \\
\text { services for business in } \\
\text { electronic form, mln. in year }\end{array}$ & 2,028 & 2,253 & 2,504 \\
\hline $\begin{array}{l}\text { Number of free hours due to } \\
\text { digitalization, mln. hours per } \\
\text { year }\end{array}$ & 17 & 22 & 34 \\
\hline $\begin{array}{l}\text { Cost savings of the state and } \\
\text { business due to digitalization } \\
\text { of public services, trillion. } \\
\text { rub. in year }\end{array}$ & 2,85 & 3,87 & 5,71 \\
\hline government cost saving & 0,21 & 0,22 & 0,23 \\
\hline business cost savings & 2,63 & 3,65 & 5,48 \\
\hline
\end{tabular}

The digitalization of cadastral registration in Western Europe, the USA and Canada has become the ground of the information base for various types of registers (real estate, forestry, water, environmental and urban planning).In most economically developed foreign countries, the cadastral registration is the unity of the fate of a land plot and real estate objects that are firmly connected with land. This relationship allows consumers of digital services of land information systems to economically and efficiently carry out the processes of transferring ownership of real estate. It also allows the subjects of state management of real estate to manage processes in the studied sector of the country more effectively [10].

According to expert opinions, the implementation of the program "Digital Economy in the Russian
Federation" in state management of real estate can be achieved with the following measures (Figure 11):

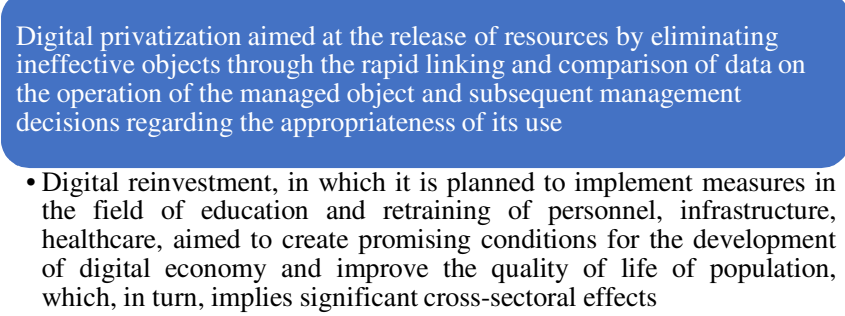

- Digital reinvestment, in which it is planned to implement measures in the field of education and retraining of personnel, infrastructure, healthcare, aimed to create promising conditions for the development of digital economy and improve the quality of life of population, which, in turn, implies significant cross-sectoral effects

\section{Intensive implementation of digital technologies: big data, artificial} intelligence, neural networks, blockchain with active investment participation of the state, in order to create favorable conditions for pusiness

\section{- Digitalization of public administration, which allows increasing the efficiency and transparency of all processes of interaction with the state, simplifying business processes in the country}

Figure 11. Activities carried out within the framework of the program "Digital Economy in the Russian Federation"

In order to implement the goals of digitalization of public administration, the technologies of the electronic document management system are used.

In order to improve the efficiency of the use of information on real estate, the Federal Service for State Registration, Cadastre and Cartography has introduced a digital project for the analysis and processing information, as well as comparison with the data contained in the register of federal property. This project has the mechanisms for analytical processing of information, which allow reducing the number of errors in data and carrying out systematic work to update information [10]. It is planned to develop a big data system in order to identify the reserves to increase the efficiency of federal property use [10].

For the implementation of the program "Digital Economy of the Russian Federation", the center of strategic developments has already proposed the idea of "State as a platform", in which the digital transformation of public administration should be based on a targeted basis of quality improvement, efficiency, consumer satisfaction, where the key factor is the well-being of citizens and economic effect.

The improved approaches to accounting and registration imply the introduction of Blockchain technologies designed to optimize the process of the registration of real estate and become the basis for the creation of open registries (Figure 12). The advantage of this technology is the ability to exclude intermediaries during accounting actions on the example of state registration of real estate. 


\section{Blockchain-technologies}

- distributed database organization system. Its work is based on the distribution of data between blocks, which can be located on computers of thousands of users in different parts of the world.

- any project created on the basis of blockchain technology can be compared to a database that allows storing the same information on many different servers

- each transaction in such a scheme is decentralized, which excludes the possibility to change or falsify data

Figure 12. Systems ofBlockchain-technologies

We propose to create a server room in the central office ofthe Federal Service for State Registration, Cadastre and Cartography.

For this, it is necessary to involve two specialists for the stable operation of ASIC-miners in the server room and one employee representing the call center for technical support of territorial departments.

The salary of an employee responsible for the mining machine is 40,000 rubles per month and the specialist representing the call center earns 20,000 rubles per month, therefore, $40,000 * 2+20,000=100,000$ rubles per month. Total costs for wages will be $100,000 * 12=$ $1,200,000$ rubles in year.

For the work of specialists, we need the buy ASICminers. The cost of one ASIC 2TH / sTerraMinerIV is 187,000 rubles. We need to buy 2 ASIC-miners in the server room; therefore it is necessary to get $187,000 * 2=$ 374,000 rubles. It is also necessary to buy 2 power supplies; the cost of one is 10,000 rubles. Their total costs will be 20,000 rubles.

Electricity costs depend on the server power consumption, $\mathrm{kW} / \mathrm{h}$; power consumption of the ASICminer, $\mathrm{kW} / \mathrm{h}$; cost of electricity, rubles/kWh; amount of time.

One device consumes $0.96 \mathrm{~kW} / \mathrm{h}$, therefore, $0.96 * 24$ $=23.04 \mathrm{~kW} /$ day is consumed by one ASIC-miner. The project needs 2 installations, $23.04 * 2=46.08 \mathrm{~kW} /$ day.

ASIC-miners work throughout the year, seven days a week, the cost of electricity is 3.8 rubles $\mathrm{Kw} / \mathrm{h}$. As a

\begin{tabular}{|c|c|c|}
\hline Stratum & Stratum area & Stratum content \\
\hline $\begin{array}{l}\text { Stratum 6: } \\
\text { Idea }\end{array}$ & $\begin{array}{l}\text { quality supply of public administration in the } \\
\text { context of digitalization }\end{array}$ & $\begin{array}{l}\text { organization of interaction between government entities using } \\
\text { distributed software in order to ensure its quality }\end{array}$ \\
\hline Stratum 5: Research & digitalization of public administration of R\&D & $\begin{array}{c}\text { creation of economic and mathematical models of real estate, models } \\
\text { of formation, implementation of the quality strategy of public } \\
\text { administration of real estate for the development of IT projects }\end{array}$ \\
\hline $\begin{array}{l}\text { Stratum 4: System } \\
\text { representation }\end{array}$ & ecosystem of digital platforms of government & $\begin{array}{c}\text { informatization of the digital ecosystem of public administration, } \\
\text { formation of interaction between digital platforms based on the } \\
\text { regulatory code of the digital space, } \\
\text { quality requirements of public administration }\end{array}$ \\
\hline $\begin{array}{l}\text { Stratum 3: } \\
\text { Conctruction }\end{array}$ & database of real estate of the Russian Federation & $\begin{array}{c}\text { creation of an information space based on the Unified State Register } \\
\text { of Real Estate to coordinate the interaction of government entities for } \\
\text { structuring and storing data on real estate }\end{array}$ \\
\hline $\begin{array}{l}\text { Stratum2: } \\
\text { Technologies }\end{array}$ & $\begin{array}{l}\text { cloud, fog and dew computing, Blockchain } \\
\text { technologies, big data processing, } \\
\text { neurotechnologies }\end{array}$ & $\begin{array}{l}\text { processing and mining the entire set of big data on the functioning of } \\
\text { real estate, extracting information from data on real estate }\end{array}$ \\
\hline $\begin{array}{l}\text { Stratum 1: } \\
\text { Embodiment }\end{array}$ & information communication system & information interaction of government entities in the Internet space \\
\hline
\end{tabular}

result, the total cost is $46.08 * 3.8 * 365=63,913$ rubles per year.

To organize a server room, we need: one personal computer which costs 50,000 rubles; a server box - 3,000 rubles; a switch - 3,000 rubles and power cables $7 *$ $600=4,200$ rubles; unlimited Internet at a cost of 1,500 rubles per month, as a result, $1,500 * 12=18,000$ rubles per year is the Internet costs.

Another cost is depreciation charges.

$$
\mathrm{A}_{\mathrm{PC}}=\left(\mathrm{C}_{\mathrm{pc}} * \mathrm{H}_{\mathrm{d}}\right),(1)
$$

where $\mathrm{C}_{\mathrm{pc}}-$ cost of $1 \mathrm{PC}$, rub. In our case it is 50000 rublesand the cost ofpower supplies 20000 rubles;

$\mathrm{H}_{\mathrm{d}}$ - depreciation rate of fixed assets per year, \%.

The cost of depreciation charges amounted to 14,000 rubles per year.

Basic costs are calculated using the following formula:

$$
3_{\mathrm{BAS}}=3_{\mathrm{TOT}}+3_{\mathrm{SOC}}+3_{\mathrm{MAT}}+3_{\mathrm{D}}+3_{\mathrm{OTHER}},(2)
$$

$3_{\mathrm{BAS}}=1200000+374000+120000+63913+$ $50000+10200+18000+14000=1750713$ рублей.

The total cost of the development of a server room will be about 2 million rubles. It is necessary to note that these costs are one-off.

With the use of this technology, it is planned to conduct about one thousand transactions per month, 12,000 transactions per year. The deal will be approximately up to 2 million rubles. Basically, up to $3 \%$ are taken by intermediaries for transactions. On average, we will be able to save about 700 million rubles a year on the services of intermediaries.

That is, the use is really reasonable and economically profitable.

The stratified representation gives the understanding of the concept of digitalization of public administration in the system of coordinates of its quality, which allows reflecting its numerous features from the point of the satisfaction of needs [11].

The digitalization stratum model allows creating an information base of public administration utility indicators and form digital models of controlled situations, taking into account the subject-object composition, goals and quality indicators. 


\section{Conclusion}

The main result of digitalization is the increase in revenue, the increase in the transparency of activities, the increase in the speed of provision of services, the decrease in resource intensity and the improvement in the quality of products and services. According to experts, mobile technologies, industrial automation, virtualization technologies, digital design and modeling have a significant impact on the results of digitalization. Digitalization gives the opportunity to improve the standard of living of the population in accordance with employment opportunities, the increase in purchasing power, the increase in social participation of citizens in the management of processes that improve the convenience of living, the development of digital services, public services and national security [12].

The above mentioned review, showing a low rating of the quality of public administration in Russia, suggests that the management of real estate in the Russian Federation reflects problems in the field of quality supply.

As it is noted in the Good Governance Guide 2014, "good governance" leads to better decisions, helps local governments meet their legislative responsibilities, and, in fact, provides an ethical framework for governance. This allows assessing the work of the government as an effective management process.

The use of digital technologies of big data, neurotechnologies, artificial intelligence and new production technologies will improve the management system based on the digitalization of economy sectors.

\section{References}

1. V.G. SvetashovMonitoring the quality of real estate management processes(Moscow, 2017)

2. M.G. Rodionov Bulletin of the Siberian Institute of Business and Information Technologie, 1, 25, 62-66 (2018)

3. T.I. Leonova, Yu.A. KalazhokovaFundamental research, 6, 1, 143-147 (2015)

4. E.V. TalapinaModernization of public administration in the information society (Moscow, 2015)

5. N. Manning, N. Parison.Public administration reform: international experience p. 35-41 (Moscow, 2003)

6. D.G. Krasilnikov, O.V. Sivintseva, E.A. TroitskayaARS ADMINISTRANDI, 2, 45-62 (2014)

7. V.V. Markin, A.V. OstashkovMonitoring of state and municipal services in the region as a strategic tool for improving the quality of regional management: experience, problems, recommendations (Moscow, 2008)

8. Report of World bank: Worldwide Governance Indicators, Retrieved from: http://info.worldbank.org/governance/wgi/\#report s.
9. M. Gross, R. ZróbekLand Use Policy, 49, 352364(2015)

10. A.A.Varlamov, S.A.Galchenko, O.V. Gvozdeva, I.V.Chuksin International agricultural journal, 63, 5 (377), 69-72, (2020)

11. S.N.Danilova Management of the balanced development of multifunctional centers for the provision of state and municipal services: abstract dis. candidate of economic sciences: (St. Petersburg, 2019)

12. O. V.Gvozdeva, M. A. Smirnova, I. V.Chuksin, M. V. Shakirova Moscow Economic Journal, 12, p.48(2020) 